\title{
Amino acid and mineral composition of milk from local Ukrainian cows and their crossbreedings with Brown Swiss and Montbeliarde breeds
}

\author{
A.A. Borshch*, A.V. Borshch, M.M. Lutsenko, S.V. Merzlov, L.T. Kosior, I.A. Lastovska and \\ L.V. Pirova \\ Department of Technology of Milk and Meat Production, Bila Tserkva National Agrarian University, \\ Bila Tserkva, 09100 - Ukraine \\ *Corresponding E-mail: borshcha@outlook.com
}

Received June 05, 2018; Accepted July 03, 2018

\begin{abstract}
ABSTRAK
Tujuan peneitian ini adalah untuk menganilis komposisi mineral susu, komposisi asam amino protein susu dan produktivitas per 305 hari masa laktasi pada hasil persilangan dibandingkan dengan bangsa murni sapi lokal Ukrania. Penelitian dilakukan pada beberapa induk sapi perah Ukranian BlackSpotted (UBS) dan hasil silangannya pada generasi pertama dengan Brown Swiss, induk-induk Uranian Red-Spotted (URS) dan hasil silangannya pada generasi dengan bangsa Montbeliarde. Pada dua peternakan terdapat masing-masing dua jenis bangsa. Komposisi mineral susu pada sapi hasil silangan lebih tinggi dibandingkan dengan bangsa murni. Kadar lemak susu sapi hasil silangan lebih tinggi 0,08$0,16 \%$, protein lebih tinggi $0,15-0,22 \%$ dan kadar Ca dan P masing-masing 2,66-8,83 dan 2,12-7,81 g susu. Protein susu pada induk hasil persilangan ditandai dengan komposisi asam amino yang lebih seimbang (EAA) dan rasio yang cocok untuk pemrosesan. Jumlah EAA pada $100 \mathrm{~g}$ protein susu induk hasil persilangan adalah 3,11-6,25\% lebih tinggi dibandingkan dengan induk bangsa murni. Induk hasil persilangan lebih tinggi dalam hal komposisi mineral susu dibandingkan induk bangsa murni. Direkomendasikan penggunaan bangsa Montbeliarde atau Brown Swiss pada peternakan komersial.
\end{abstract}

Kata kunci: sapi perah, asam amino, element mineral, kebutuhan manusia

\begin{abstract}
The aim of this study was to analyze the mineral composition of milk, the amino acid composition of milk protein, and the productivity per 305 days of lactation in crossbred cows compared to pure-breed local Ukrainian analogues. The research was conducted at cows of the Ukrainian Black-Spotted (UBS) dairy breed and crossbred cows of the first-generation obtained as a result of crossing with Brown Swiss breed and at cows of the Ukrainian Red-Spotted (URS) dairy breed and crossbred cows of the firstgeneration obtained by crossing of the URS dairy breed with Montbeliarde breed. In both farms there were two groups of pure-breed and crossbred cows-analogues. The mineral composition of milk and its technological properties in crossbred cows were higher compared to the pure-breed analogues. The fat content of milk crossbred cows exceeded by $0.08-0.16 \%$, protein exceeded by $0.15-0.22 \%$, and the main trace elements include $\mathrm{Ca}$ and $\mathrm{P}-$ by $2.66-8.83$ and $2.12-7.81 \mathrm{mg} / 100 \mathrm{~g}$ of milk, respectively. Milk protein of crossbred cows was marked by a more balanced composition of essential amino acids (EAAs) and their ratio suitable for processing. The amount of EAAs in $100 \mathrm{~g}$ of milk protein of crossbred cows was 3.11-6.25\% higher compared to local analogues. Crossbred cows dominated pure-breed analogues by the mineral composition of milk. The authors recommend the use of Montbeliarde or Brown Swiss
\end{abstract}


breeds in commercial herds to improve the technological properties of milk.

Keywords: dairy cows, breeds, amino acids, major mineral elements, human need

\section{INTRODUCTION}

The high potential of milk production Holstein cows has led to its domination in many parts of the world due to the high productive potential and good adaptive features (Dechow et al., 2007; Heins and Hansen, 2012). Given this fact, breeders often ignore the functional features of Holsteins, which have led to a further decline in productivity of matured cows, deterioration of health, and hence additional costs for veterinary measures, problems with reproduction, and the duration of economic use (longevity). All these reduces the productive advantages of the Holstein breed.

Recently, global interest in crossbreeding has increased due to the improvement of the functional state of local domestic cows and the composition of milk components (Dezetter et al., 2015). Other aspects such as the suitability of milk for production of certain types of products and also the resistance of cows to metabolic and non-infectious diseases affect the increasing use of this breeding direction in many developed countries (Heins et al., 2012). The most common breeds used to improve reproduction, longevity, and qualitative composition of milk in the United States are Brown Swiss, Jersey, Montbeliarde, Ayrshire, however, in the countries of the European Union, besides those are also used the Swedish, Norwegian, and Danish Red breeds.

Moreover, one of the criteria of the milk quality as a feedstock is its suitability for the further processing (Reykdal et al., 2011; Guetouache et al., 2014). Likewise, the qualitative composition of milk is due to genetic factors (species, breed, line) and at the same time depends on paratype factors: age, lactation stage, type of feeding, season, and climatic conditions (Li et al., 2007; Appuhamy et al., 2011; Ghassemi et al., 2017). Along with the main qualitative parameters of milk such as fat, protein, lactose and dry matter, its fatty acid, amino acid and mineral composition, as well as pro- and antioxidant properties are equally important $(\mathrm{Wu}$ and Knabe, 1994; Bates and Prentice, 1996; Fuente et al.,1997; Liang et al., 2018)). Knowledge of these indicators is a key factor for determining of the suitability of milk for processing into certain types of products (Zurera-
Cosano et al., 1994; Bos et al., 2003; Stojanovska et al., 2018). Therefore, the aim of this study was to analyze the mineral composition of milk, the amino acid composition of milk protein, and the productivity per 305 days of lactation in crossbred cows compared to pure-breed local Ukrainian analogues.

\section{MATERIALS AND METHODS}

\section{Materials}

The research was conducted at the dairy farm "Mikhailivske", Mikhailivka village (49 11 '52" North latitude, 28 43'29" East longitude) of Vinnitsa region with the cows of the Ukrainian Black-Spotted (UBS) dairy breed and crossbred cows of the first-generation obtained as a result of crossing with Brown Swiss breed and at the dairy farm "Azorel", village Mukhivka (48 $57^{\prime} 01^{\prime \prime}$ North latitude, 28 $47^{\prime} 09^{\prime \prime}$ East longitude) of Vinnitsa region with the cows of the Ukrainian Red-Spotted (URS) dairy breed and crossbred cows of the first-generation obtained from crossing of the URS dairy breed with Montbeliarde breed. In both farms there were two groups of pure-breed and crossbred cowsanalogues. Ten cows were used in each group.

\section{Methods}

The accounting of milk productivity of the experimental cows was carried out according to daily and monthly yields. The amino acid compositions of milk proteins and its mineral composition was determined and assessed at the State Research and Development Control Institute of Veterinary Preparations and Feed Supplements (Lviv) by the method of capillary electrophoresis using the system of capillary electrophoresis "Kapel 105/105M" (Ukraine). The system of capillary electrophoresis "Kapel 105/105M" with a positive polarity of a high voltage source (internal diameter of the capillary is 75 micrometer, full length of the capillary is $60 \mathrm{~cm}$, effective length is $50 \mathrm{~cm}$ ), equipped with special software based on a personal computer.

The method for determining of amino acid in milk was based on the spreading of tests by acid hydrolysis with their transition into free forms of phenylthiocarbamil derivatives (PTC derivatives), their further separation and quantitative 
determination by the method of capillary electrophoresis. The determination of amino acid content was used the standard set LAA-21 (USA). The detection was carried out in the UV area of the spectrum at the wavelength of $254 \mathrm{~nm}$. Determination of macro elements in milk was based on acid hydrolysis of samples, further separation, and quantitative determination of cations by capillary electrophoresis method. The components were detected by indirect absorption at the wavelength of $267 \mathrm{~nm}$. For analysis of the amino acid and mineral composition, milk samples from each of the experimental cows were cooled to the temperature $6 \pm 2^{\circ} \mathrm{C}$.

The obtained data were statistically processed using STATISTICA (Version 11.0, 2012) software. The student's $t$-test was used to estimate the statistical significance of the obtained values. Data were considered significant at level of 5, 1 and $0.1 \%$ (Sokal and Rohlf, 1995).

\section{RESULTS AND DISCUSSION}

Recently, crossbreeding, as an element of commercial herds improvement, has been studied mainly from the point of view of its influence on productive and reproductive features, qualitative composition of milk and duration of economic use of cows. Furthermore, the study of protein and mineral composition of crossbred cows' milk, which is mostly local or continental, was not carried out in full. Currently, there is no information about the influence of crossbreeding on the protein composition of the cows of the Holstein breed with the Jersey, Montbeliarde or Brown Swiss breeds. However, Decow et al. (2007) noted that the first generation of Holstein and Jersey crosses was marked by higher levels of fat, protein, and lower somatic cells. These factors level the difference in productivity, which was somewhat higher in purebred Holstein cows.

This is to some extent coincides avoid we in which the crossbred cows of the first generation of UBS with Brown Swiss breeds cows synthesized more fat + protein per lactation, and had a higher indicator of theoretically possible yield of rennet cheese than of pure-breed ones. Pure UBS and URS cows produced 106.45 and $218.36 \mathrm{~kg}$ more milk than crossbred analogues per 305 days of lactation, thereby emphasizing the potential loss of some milk volume associated with crossbreeding (Table 1).

At the same time, the mass fraction of fat and protein were higher at crossbred cows by 0.08 and $0.15 \%$ at the crossbreed of UBS with Brown Swiss breeds and by 0.16 and $0.22 \%$ at the crossbred cows of the URS with Montbeliarde breeds, respectively. Also, the synthesis of fat+protein was $7.04 \mathrm{~kg}$ more UBS and Brown Swiss breeds and $8.74 \mathrm{~kg}$ more at URS and Montbeliarde crossbred cows.

Research results by Heins and Hansen (2012), who studied the influence of the crossbreeding cows of Holstein and Montbeliarde breeds on productivity, the qualitative composition of milk and calf crop in 6 commercial California herds, reported that during 305 days of lactation the crossbred cows synthesized less fat and protein by 3\% than purebred Holstein cows. The authors recommend to use this combination of crossbreeding for increasing of the annual calf delivery, reducing of the risks associated with the severity of calving and improvement of the udder shape and to use it in herds with average productivity. Our studies do not inconsistent with the above mentioned, as at the crosses of the URS with Montbeliarde breeds, when we have observed the results of fat and protein by $1.96 \%$ higher and by $1.49 \%$ higher than of theoretically possible yield of rennet cheese than pure-breed analogues.

An important indicator which marks the value of milk as a feedstock for food production is its mineral composition (Cashman, 2006; Patra et al., 2008; Claeys et al., 2014). The major mineral elements of milk are biologically significant constituents that are necessary for normal development and livelihoods (Stawars et al., 2007; Cofani et al., 2012; Gürbay et al., 2012). The number of major mineral elements in milk is an important indicator of its biological activity. They are essential for the development of the aroma - they form bacteria that produce aromatic substances that are involved in the creation of the aroma of cultured milk foods, sour cream butter, as well as in the formation of a picture in cheese (Schöne et al., 2009; Rafiq et al., 2016). In addition, they are part of the buffer systems of milk and casein micelles.

The most important major mineral elements of milk are calcium and phosphorus. They are contained in an easily digestible form and harmoniously balanced among themselves (Tripathi et al., 1999; Moreno-Montoro et al., 2015). The physiological and biochemical role of $\mathrm{Ca}$ and $\mathrm{P}$ is very important in human nutrition, especially for children, in the processing of feed stock and plays a pivotal role in the dispensing of 
Table 1. Productivity, Composition and Technological Properties of Milk at Cows of Different Genotypes

\begin{tabular}{|c|c|c|c|c|}
\hline \multirow{3}{*}{ Indicators } & \multicolumn{4}{|c|}{ Breed } \\
\hline & UBS & $\begin{array}{l}\text { UBS x Brown } \\
\text { Swiss }\end{array}$ & URS & $\begin{array}{c}\text { URS x } \\
\text { Montbeliarde }\end{array}$ \\
\hline & $\mathrm{n}=10$ & $\mathrm{n}=10$ & $\mathrm{n}=10$ & $\mathrm{n}=10$ \\
\hline $\begin{array}{l}\text { Milk yield per } 305 \text { days } \\
\text { of lactation, } \mathrm{kg}\end{array}$ & $6302.81 \pm 33.29$ & $6196.36 \pm 28.43^{* * *}$ & $6478.20 \pm 38.31$ & $6259.84 \pm 33.72^{* * *}$ \\
\hline Mass fraction of fat $\%$ & $3.74 \pm 0.03$ & $3.82 \pm 0.09$ & $3.73 \pm 0.05$ & $3.89 \pm 0.06^{* * *}$ \\
\hline $\begin{array}{l}\text { Mass fraction of } \\
\text { protein, } \%\end{array}$ & $3.03 \pm 0.02$ & $3.18 \pm 0.03^{* * *}$ & $3.16 \pm 0.04$ & $3.38 \pm 0.03^{* * *}$ \\
\hline $\begin{array}{l}\text { Fat }+ \text { protein has been } \\
\text { synthesized per } \\
\text { lactation, } \mathrm{kg}\end{array}$ & $426.69 \pm 11.42$ & $433.73 \pm 14.36$ & $446.34 \pm 12.59$ & $455.08 \pm 16.27$ \\
\hline
\end{tabular}

newborn calves. In the milk of the crossbred cows of the UBS with Brown Swiss breeds, the content of Ca by $2.66 \mathrm{mg} / 100 \mathrm{~g}$, and $\mathrm{P}$ by $2.12 \mathrm{mg} / 100 \mathrm{~g}$ was higher than that of pure-bred cows. Meanwhile, the ratio of these elements at the crossbred cows was slightly superior to purebreed analogues (1.31:1 versus $1.30: 1)$ as presented in Table 2. The crossbred cows of URS with Montbeliarde breeds exceeded pure-breed ones in the content of $\mathrm{Ca}$ and $\mathrm{P}$ in milk by 8.83 and $7.81 \mathrm{mg} / 100 \mathrm{~g}$, respectively. They also had a greater ratio of $\mathrm{Ca}: \mathrm{P}(1.33: 1$ to $1.32: 1)$.

$\mathrm{K}$ and $\mathrm{Na}$ salts are contained in milk in the ionic-molecular state in the form of chlorides, phosphates and citrates. They have great physiological significance providing a certain amount of osmotic pressure of blood and milk, which is necessary for normal livelihoods (Cashman, 2006; Zamberlin et al., 2012). The content of $\mathrm{K}$ and $\mathrm{Na}$ in milk of crosses was somewhat more of their content in milk of purebreed analogues. Thus, in the milk of the UBS with Brown Swiss breeds, their content was by 9.08 and $4.76 \mathrm{mg} / 100 \mathrm{~g}$ more, and at the URS and Montbeliarde breeds ones their content was by 5.68 and $0.71 \mathrm{mg} / 100 \mathrm{~g}$ higher than that of purebreed UBS and URS cows respectively.

It is known that $\mathrm{S}$ plays a vital role in the human body, since it participates in all, without exception, metabolic processes in the body.
Equally important functions of $\mathrm{S}$ are stabilization of blood glucose level, anti-allergic action, oxygen balance maintenance, blood coagulation, resistance to radioactive emissions, etc (Tripathi et al., 1999). The content of $\mathrm{S}$ in milk of purebred UBS cows was $0.19 \mathrm{mg} / 100 \mathrm{~g}$, and exceeded its content at the crosses with Brown Swiss breeds. In the meanwhile, the crosses of URS with Montbeliarde breeds, on the contrary, the content of $\mathrm{S}$ was $0.31 \mathrm{mg} / 100 \mathrm{~g}$ higher than at pure URS analogues. The content of $\mathrm{Mg}$ in milk, which is responsible for the development of immunity and resistance to intestinal diseases in the body, UBS cows somewhat dominated the crossed with Brown Swiss breeds analogues - by $0.06 \mathrm{mg} / 100$ $\mathrm{g}$. The crosses of URS and Montbeliarde breeds cows had the content of $\mathrm{Mg}$ in milk higher by $0.56 \mathrm{mg} / 100 \mathrm{~g}$ than at pure URS cows.

When analyzing the content of certain EAAs in the milk of cows of the studied breeds, it can be known that the largest absolute amount belongs to leucine $0.291-0.322 \mathrm{~g} / 100 \mathrm{~g}$ of milk, which is an integral part of casein, phenylalanine+tyrosine $(0.285-0.317 \mathrm{~g} / 100 \mathrm{~g}$ of milk) and lysine of $0.183-$ $0.214 \mathrm{~g} / 100 \mathrm{~g}$ of milk, and the minimum methionine+cystine $(0.100-0.131 \mathrm{~g} / 100 \mathrm{~g}$ of milk) as presented in Table 3. In the milk of crossbred cows, somewhat higher levels of EAA content were observed in $100 \mathrm{~g}$ of protein, with the exception of only leucine, whose content at UBS 
Table 2.The Content of Macro Mineral Elements in the Milk of Cows

\begin{tabular}{lcccc}
\hline \multirow{2}{*}{ Indicators } & \multicolumn{4}{c}{ Breed } \\
\cline { 2 - 5 } & $\mathrm{n}=10$ & $\mathrm{n}=10$ & $\mathrm{n}=10$ & $\mathrm{n}=10$ \\
\hline $\mathrm{Ca}, \mathrm{mg} / 100 \mathrm{~g}$ & $105.76 \pm 0.83$ & $108.42 \pm 0.86^{*}$ & $105.51 \pm 2.03$ & $114.34 \pm 2.05^{* * *}$ \\
$\mathrm{P}, \mathrm{mg} / 100 \mathrm{~g}$ & $81.08 \pm 0.73$ & $83.20 \pm 0.89$ & $78.37 \pm 1.03$ & $86.18 \pm 1.20^{* * *}$ \\
$\mathrm{~K}, \mathrm{mg} / 100 \mathrm{~g}$ & $87.33 \pm 0.74$ & $96.41 \pm 0.87^{* * *}$ & $81.75 \pm 0.89$ & $87.43 \pm 0.94^{* * *}$ \\
$\mathrm{Na}, \mathrm{mg} / 100 \mathrm{~g}$ & $36.60 \pm 0.52$ & $41.36 \pm 0.38$ & $42.37 \pm 0.53$ & $43.08 \pm 0.47$ \\
$\mathrm{~S}, \mathrm{mg} / 100 \mathrm{~g}$ & $25.81 \pm 0.08$ & $25.62 \pm 0.09$ & $22.84 \pm 0.27$ & $23.15 \pm 0.38$ \\
$\mathrm{Mg}, \mathrm{mg} / 100 \mathrm{~g}$ & $11.86 \pm 0.07$ & $11.80 \pm 0.12$ & $10.28 \pm 0.08$ & $10.84 \pm 0.06$ \\
$\mathrm{Ca}: \mathrm{P}$ & $1.30: 1$ & $1.31: 1$ & $1.32: 1$ & $1.33: 1$ \\
\hline
\end{tabular}

*** $\mathrm{P}<0.001$ as compared with UBS and UBR groups. UBS: Ukrainian Black-Spotted dairy breed, URS: Ukrainian Red-Spotted dairy breed

cows was by $0.04 \mathrm{~g}$ higher than the content of crosses with Brown Swiss breed analogues. The content of aromatic acids (phenylalanine and tyrosine), which affect the taste quality of milk, was at the level of 0.285-0.317 g/ $100 \mathrm{~g}$ of milk, with a slightly lower content detected at pure cows $-0.285 \mathrm{~g} / 100 \mathrm{~g}$ of milk.

Among the non-essential amino acids (NEAA), the highest content the glutamic acid $(0.564-0.640 \mathrm{~g} / 100 \mathrm{~g}$ milk) and proline $(0.243$ $0.298 \mathrm{~g} / 100 \mathrm{~g}$ milk) had, and the smallest content the alanine had, which is able to provide a specific taste of feed stock for cheese making Brown Swiss 0.063-0.080 g/100 g of milk (Shahein and Soliman, 2014). As it is known, in $100 \mathrm{~g}$ of protein of high biological value, the amount of EAA should be not less than $40 \mathrm{~g}$ (WHO, 2007). In the analyzed milk of pure-bred UBS cows and the crosses of UBS with Brown Swiss breed cows this indicator constituted 43.41 and $44.76 \mathrm{~g}$, and at URS cows and crosses of URS with Montbeliarde breed cows (41.08 and $43.65 \mathrm{~g}$ ), respectively. Existing research suggest that the mineral and AA composition of crossbred cow's milk, along with genetic features, is also influenced by the climatic zone and the feed base of a certain area.

The results of Makepula et al. (2011) indicate that in crossbred cows Nguni and local South African breeds protein composition as to the content of methionine, threonine, tyrosine, glycine and proline was lower than at the Nguni purebred cows. Likewise, in the milk of Nguni cows, there were higher levels of calcium and phosphorus content in comparison with crossbred analogues. Instead, Sun et al. (2014) and Ren et al. (2015) in their studies conducted in the Guangxi Autonomous Region of China noted that the quality content of the milk of crossbred buffalo Murrah river Buffalo x Guangxi swamp Baffalo dominated by fat, protein and all but cysteine, EAA purebred Murrah river Buffalo. It is known, that cattle and buffalo are subfamily of bulls (Bovinae), and therefore our comparison takes place.

The results of our studies coincide with the conclusions of Sun et al. (2014) and Ren et al. (2015). The first generation $\left(F_{1}\right)$ of the UBS with Brown Swiss breeds cows and of the URS with Montbeliarde breed cows dominated over the pure-breed local breeds, both by mineral composition and by the content of EAA in milk.

One of the most important components of milk proteins is the functional group of immuneactive AAs, which, in addition form the immune active proteins of the body, accelerate the production of T-lymphocytes, specific antibodies, and also have their own immunological activity and are perspective as immune modulators (Niven et al.,1998; Moshel et al., 2006; Mazhitova et al., 2015). The highest amount of immune-active AAs was in the milk protein of crossbred cows at the crosses of URS with Montbeliarde breeds cows, this indicator was $501.6 \mathrm{mg} / \mathrm{g}$, which is by 9.6 
Table 3. Amino Acid Composition of Protein in Milk of Cows of Different Breeds

\begin{tabular}{|c|c|c|c|c|c|c|c|c|}
\hline \multirow{4}{*}{$\begin{array}{c}\text { Name of } \\
\text { AA }\end{array}$} & \multicolumn{8}{|c|}{ Breed } \\
\hline & \multirow{2}{*}{\multicolumn{2}{|c|}{$\begin{array}{l}\text { UBS } \\
\mathrm{n}=10\end{array}$}} & \multirow{2}{*}{\multicolumn{2}{|c|}{$\begin{array}{l}\text { UBSxBrown Swiss } \\
\mathrm{n}=10\end{array}$}} & \multirow{2}{*}{\multicolumn{2}{|c|}{$\begin{array}{l}\text { URS } \\
n=10\end{array}$}} & \multirow{2}{*}{\multicolumn{2}{|c|}{$\begin{array}{c}\text { URSx Montbeliarde } \\
\mathrm{n}=10\end{array}$}} \\
\hline & & & & & & & & \\
\hline & $\begin{array}{l}\mathrm{g} / 100 \mathrm{~g} \\
\text { of milk }\end{array}$ & $\begin{array}{l}\mathrm{g} / 100 \mathrm{~g} \text { of } \\
\text { protein }\end{array}$ & $\begin{array}{l}\mathrm{G} / 100 \mathrm{~g} \\
\text { of milk }\end{array}$ & $\begin{array}{l}\mathrm{G} / 100 \mathrm{~g} \\
\text { of protein }\end{array}$ & $\begin{array}{l}\mathrm{G} / 100 \mathrm{~g} \\
\text { of milk }\end{array}$ & $\begin{array}{l}\mathrm{G} / 100 \mathrm{~g} \\
\text { of protein }\end{array}$ & $\begin{array}{l}\mathrm{G} / 100 \mathrm{~g} \\
\text { of milk }\end{array}$ & $\begin{array}{l}\mathrm{G} / 100 \mathrm{~g} \\
\text { of protein }\end{array}$ \\
\hline \multicolumn{9}{|c|}{ EAA } \\
\hline Lys & 0.199 & 6.58 & 0.214 & 6.73 & 0.183 & 5.81 & 0.214 & 6.34 \\
\hline Met+Cys & 0.100 & 3.32 & 0.117 & 3.71 & 0.106 & 3.38 & 0,131 & 3.88 \\
\hline Thr & 0.136 & 4.50 & 0.144 & 4.54 & 0.128 & 4.06 & 0.148 & 4.40 \\
\hline Val & 0.147 & 4.86 & 0.167 & 5.28 & 0.167 & 5.29 & 0.195 & 5.77 \\
\hline Leu & 0.299 & 9.87 & 0.312 & 9.83 & 0.291 & 9.22 & 0.322 & 9.53 \\
\hline Ile & 0.146 & 4.85 & 0.156 & 4.92 & 0.135 & 4.28 & 0.147 & 4.35 \\
\hline Phe+Tyr & 0.285 & 9.43 & 0.310 & 9.75 & 0.285 & 9.04 & 0.317 & 9.38 \\
\hline \multicolumn{9}{|l|}{ NEAA } \\
\hline Pro & 0.243 & 8.04 & 0.262 & 8.26 & 0.290 & 9.18 & 0.298 & 8.83 \\
\hline Ser & 0.175 & 5.78 & 0.179 & 5.65 & 0.168 & 5.33 & 0.185 & 5.50 \\
\hline Ala & 0.116 & 3,83 & 0.127 & 4.01 & 0.124 & 3.94 & 0.134 & 3.97 \\
\hline Gly & 0.063 & 2.08 & 0.067 & 2.13 & 0.076 & 2.42 & 0.080 & 2.37 \\
\hline His $^{\#}$ & 0.088 & 2.93 & 0.095 & 3.00 & 0.086 & 2,75 & 0.097 & 2.89 \\
\hline $\operatorname{Arg}^{\#}$ & 0.105 & 3.48 & 0.111 & 3.52 & 0.111 & 3.54 & 0.119 & 3.55 \\
\hline Asp & 0.170 & 5.63 & 0.181 & 5.72 & 0.176 & 5.59 & 0.191 & 5.66 \\
\hline Glu & 0.564 & 18.62 & 0.597 & 18.80 & 0.601 & 19.03 & 0.640 & 18.94 \\
\hline
\end{tabular}

${ }^{\text {\# }}$ Partially essential AAs are essential for baby food. UBS: Ukrainian Black-Spotted dairy breed, URS: Ukrainian Red-Spotted dairy breed

$\mathrm{mg} / \mathrm{g}$ more than at pure-bred URS cows, and at the crosses of UBS cows with Brown Swiss breeds cows $(496.5 \mathrm{mg} / \mathrm{g})$, that is by $8.7 \mathrm{mg}$ more than at UBS cows (Table 4).

The content of glycogenic AAs significantly correlates with the state of the main components of immunity. These AAs have a positive effect on the formation of immunity, and also are used to synthesize energy (Mettler et al., 2010; Mazhitova and Kulmyrzaev, 2016). Crossbred cows dominated the pure-bred cows by the content of glycogenic amino acids: crosses of UBS with Brown Swiss breeds cows by $15.5 \mathrm{mg}$, and URS with Montbeliarde breeds cows by 12.5 mg over UBS and URS, respectively.

By the content of ketogenic AAs (which are important for maintenance of the energy balance, serve as fuel for muscle tissue and kidneys, and also prevent excessive mobilization of fatty acids from fat depots) and sulfur-containing AA (involved in the synthesis of proteins and nucleic acids, the construction of disulfide compounds, provision of glutathione synthesis, in protection of cells from active forms of oxygen, and increasing of cellular resistance to toxicants) there was not found out any significant advantage of crossbred cows over purebred animals (Wu, 2009).

In order to find out the optimal ratios of EAA in milk protein of cows of investigated breeds, a comparison of their content with an aminogram of the standard form (according to methionine+cystine) of "ideal" chicken egg protein (WHO, 2007) has been executed. Under comparison with the "ideal protein" aminogram, it was discovered that milk of the studied breeds did not contain $\mathrm{AA}$, the ratios of which were less than 
optimal (Table 5). The closest to the "ideal" was the aminogram of milk protein of crosses of the URS breed with Montbeliarde breeds, and the maximum differences have been observed in the AA protein formula of the milk of UBS cows; AA formula of milk proteins at crosses of UBS and Brown Swiss breeds with URS cows occupies intermediate values (with a slight advantage of UBS crossbreeds).

It should be noted that the highest excess content, in relation to the standard, has been marked by leucine and the sum of phenylalanine+tyrosine in the milk of all studied breeds.

\section{CONCLUSION}

Crossbred cows dominated pure-breed analogues by the mineral composition of milk. Milk protein of crossbred cows was marked by a more balanced composition of EAA and their ratio suitable for processing. The authors recommend the use of Montbeliarde or Brown Swiss breeds in commercial herds to improve the

Table 4. Content and Ratio of Protein AA in Milk of Cows of Different Breeds, mg/g

\begin{tabular}{lcccc}
\hline & \multicolumn{4}{c}{ Breed } \\
\cline { 2 - 5 } \multicolumn{1}{c}{ Name of AA } & UBS & $\begin{array}{c}\text { UBSxBrown } \\
\text { Swiss }\end{array}$ & URS & $\begin{array}{c}\text { URS x } \\
\text { Montbeliarde }\end{array}$ \\
\cline { 2 - 5 }$\sum$ EAA & $\mathrm{n}=10$ & $\mathrm{n}=10$ & $\mathrm{n}=10$ & $\mathrm{n}=10$ \\
$\sum$ NEAA & $434.1 \pm 4.40$ & $447.6 \pm 4.22^{*}$ & $410.8 \pm 7.02$ & $436.5 \pm 5.61^{*}$ \\
$\sum$ TAA & $503.9 \pm 6.52$ & $510.9 \pm 5.28$ & $517.7 \pm 8.34$ & $517.1 \pm 6.73$ \\
$\Sigma$ EAA/ $\Sigma$ NEAA & $938.0 \pm 7.14$ & $958.5 \pm 7.02$ & $928.5 \pm 8.08$ & $953.6 \pm 7.53^{*}$ \\
AAindex $(\Sigma$ EAA/ $\Sigma$ TAA) & 0.86 & 0.87 & 0.79 & 0.84 \\
$\sum$ immune active AA & 0.462 & 0.466 & 0.442 & 0.457 \\
$\sum$ glycogenic AA & $487.8 \pm 2.93$ & $496.5 \pm 2.62^{*}$ & $492.0 \pm 3.09$ & $503.6 \pm 3.17^{*}$ \\
$\sum$ sulfur-containing AA & $630.7 \pm 4.38$ & $646.2 \pm 4.89^{*}$ & $645.1 \pm 4.42$ & $657.6 \pm 4.16$ \\
$\sum$ ketogenic AA & $33.2 \pm 0.08$ & $37.1 \pm 0.12^{* * *}$ & $33.8 \pm 0.17$ & $38.8 \pm 0.16^{* * *}$ \\
\hline
\end{tabular}

${ }^{*} \mathrm{P}<0.05 ; * * \mathrm{P}<0.01 ;{ }^{* * *} \mathrm{P}<0.001$ as compared with UBS and UBR groups. UBS: Ukrainian BlackSpotted dairy breed, URS: Ukrainian Red-Spotted dairy breed

Table 5. Amino Acid Formula of Cows of Different Breeds According to Methionine+Cystine and Human Needs

\begin{tabular}{lccccccc}
\hline \multicolumn{1}{c}{ Breeds } & Met+Cys & Lys & Thr & Val & Leu & Ile & Phe+Tyr \\
& 1.0 & 1.57 & 1.14 & 1.43 & 2.00 & 1.14 & 1.71 \\
\hline & 1.0 & 1.98 & 1.36 & 1.46 & 2.97 & 1.46 & 2.84 \\
UBS, n=10 & 1.0 & 1.81 & 1.23 & 1.43 & 2.65 & 1.32 & 2.62 \\
UBSxBrown Swiss, $\mathrm{n}=10$ & 1.0 & 1.72 & 1.20 & 1.57 & 2.72 & 1.26 & 2.67 \\
URS, n=10 & 1.0 & 1.64 & 1.15 & 1.49 & 2.46 & 1.16 & 2.41 \\
URSxMontbeliarde, $\mathrm{n}=10$ & & & & & & & \\
\hline
\end{tabular}


technological properties of milk.

\section{REFERENCES}

Appuhamy, J.A.D.R.N, J.R. Knapp, O. Becvar, J. Escobar and M.D. Hanigan. 2011. Effects of jugular-infused lysine, methionine, and branched-chain amino acids on milk protein synthesis in high-producing dairy cows. J. Dairy Sci., 94(4): 1952-1960.

Ataro, A., R.I. McCrindle, B.M. Botha. C.M.E. McCrindle and P.P. Ndibewu. 2008. Quantification of trace elements in raw cow's milk by inductively coupled plasma mass spectrometry (ICP-MS). Food Chem. 111(1):243-248.

Bates, C.J and A. Prentice. 1996. Vitamins, mineral and essencial trace elements. In: Drugs and Human Lactation. (P.N. Bennett, eds). Second Ed. Elsevier Science.

Bos, C., C.C. Metges, C. Gaudichon, K.G. Petzke, M.E. Pueyo, C. C. Morens, J. Everwand, R. Benamouzig and D. Tomé. 2003. Postprandial kinetics of dietary amino acids are the main determinant of their metabolism after soy or milk protein ingestion in humans. J. Nutr. 133(5):1308-1315.

Claeys W.L., C. Verraes, S. Cardoen, J. De Block, A. Huyghebaert, K. Raes, K. Dewettinck and L. Herman. 2014. Consumption of raw or heated milk from different species: An evaluation of the nutritional and potential health benefits. Food Control. 42:188-201.

Cashman, K.D. 2006. Milk minerals (including trace elements) and bone health. International Dairy Journal, 16:1389-1398.

Cofani, L.G., E.A. Fernandes, S.S. Cofani, M.A. Bacchi, G.A. Sarries and F.J. Barbosa. 2012. Macro, minor and trace elements in bovine milk from two Brazilian dairy regions. J. Radioanalyt. Nuclear Chem. 291:207-211.

Dechow, C.D., G.W. Rogers, J.B. Cooper, M.I. Phelps and A.L. Mosholder. 2007. Milk, fat, protein, somatic cell score, and days open among Holstein, Brown Swiss, and their crosses. J. Dairy Sci. 90: 3542-3549.

Dezetter, C., H. Leclerc, S. Mattalia, A. Barbat, D. Boichard and V. Ducrocq. 2015. Inbreding and Crossbreeding parameters for production and fertility traits in Holstein, Montbeliearde and Normande cows. J. Dairy Sci. 98(7):4904-4913.

Fuente, M.D.L., A. Olano and M. Juárez. 1997. Distribution of calcium, magnesium, phosphorus, zinc, manganese, copper and iron between the soluble and colloidalphases of ewe's and goat's milk. Lait. 77:515-520.

Ghassemi, N.J., B.W. Kim and B.H. Lee. 2017. Coat and hair color: hair cortisol and serotonin levels in lactating Holstein cows under heat stress conditions. Anim. Sci. 88(1): 190-194.

Guetouache, M., B. Guessas and S. Medjekal. 2014. Composition and Nutritional value of raw milk. Biol. Sci. and Pharmac. Res. 2 (10):115-122.

Gürbay, A., M. Charehsaz, A. Eken, A.Sayal, G. Girgin, M. Yurdakök, Ş. Yiğit, D. Demir Erol, G. Şahin and A. Aydin. 2012. Toxic Metals in Breast Milk Samples from Ankara, Turkey: Assessment of Lead, Cadmium, Nickel, and Arsenic Levels. Biol. Trace Elem. Res.149(1):117-122.

Heins, B.J. and L.B. Hansen. 2012. Short communication: Fertility, somatic cell score, and production of Normande $\times$ Holstein, Montbéliarde $\times$ Holstein, and Scandinavian Red $\times$ Holstein crossbreds versus pure Holsteins during their first 5 lactations. J. Dairy Sci. 95(2):918-924.

Heins, B.J., L.B. Hansen and A. De Vries. 2012. Survival, lifetime production, and profitability of crossbreds of Holstein with Normande, Montbéliarde, and Scandinavian Red compared to pure Holstein cows. J. Dairy Sci. 95(2): 1011-1021.

Li, P., Y.L. Yin, D. Li and S.W. Kim. 2007. Amino acids and immune fuction. Br. J. Nutr. 98(2):237-252.

Liang, K., Y. Zhao, J. Han, P. Liu, J. Qiu, D. Zhu, Y. Qin, L. Lu and X. Wang. 2018. Fatty acid composition, vitamin A content and oxidative stability of milk in China. J. App. Anim. Res. 46 (1): 566-571.

Mapekula, M., M. Chimonyo, C. Mapiye and K. Dzama. 2011. Fatty acid, amino acid and mineral composition of milk from Nguni and local crossbred cows in South Africa. J. Food Comp. Analysis. 24(4-5):529-536.

Mazhitova, A. T. and A.A. Kulmyrzaev. 2016. Determination of amino acid profile of mare milk produced in the highlands of the Kyrgyz Republic during the milking season. J. Dairy Sci., 99 (4): 2480-2487.

Mazhitova, A. T., A.A. Kulmyrzaev, Z.E. Ozbekova and A. Bodoshev. 2015. Amino acid and fatty acid profile of the Mare's milk produced on Suusamyr pastures of the 
Kyrgyz Republic during lactation period. Proc.-Soc. Behav. Sci. 195: 2683-2688.

Mettler, S., N. Mitchell and K. D. Tipton. 2010. Increased protein intake reduces lean body mass loss during weight loss in athletes. Med. Sci. Sports Exerc. 42(2):326-337.

Moreno-Montoro, M., M. Ollala, R. GiménezMartínez, T. Bergillos-Meca, M.D. RuizLópez, C. Cabera-Vique, R. Artacho and M Navarro-Alarcón. 2015. Ultrafiltration of skimmed goat milk increases its nutritional value by concentrating nonfat solids such as proteins, $\mathrm{Ca}, \mathrm{P}, \mathrm{Mg}$, and $\mathrm{Zn}$. J. Dairy Sci. 98(11):7628-34.

Moshel, Y., R.E. Rhoads and I. Barash. 2006. Role of amino acids in translational mechanisms governing milk protein synthesis in murine and ruminant mammary epithelial cells. J. Cellular Biochem. 98(3): 685-700.

Niven, G.W., D.J. Knight and F. Mulholland. 1998. Change in the concentrations of free amino acids in milk during growth of Lactococcus lactis indica phipasic nitrogen metabolism. J. Dairy Res. 65(1):101-107.

Patra, R.C., D. Swarup, P. Kumar, D. Nandi, R. Naresh and S.L. Ali. 2008. Milk trace elements in lactating cows environmentally exposed to higher level of lead and cadmium around different industrial units. Sci. Total Environ. 404:36-43.

Rafiq, S., N. Huma, S. Pasha, A. Sameen, O. Mukhtar and M.I. Khan. 2016. Chemical Composition, Nitrogen Fractions and Amino Acids Profile of Milk from Different Animal Species. Asian-Australas. J. Anim. Sci. 29(7):1022-1028.

Ren, D.X., C.X. Zou, B. Lin, Y.L. Chen, X.W. Liang, and J.X. Liu. 2015. A Comparison of Milk Protein, Amino Acid and Fatty Acid Profiles of River Buffalo and Their $F_{1}$ and $F_{2}$ Hybrids with Swamp Buffalo in China. Pakistan J. Zoology. 47(5):1459-1465.

Reykdal, O., S. Rabieh, L. Steingrimsdottir and H. Gunnlaugsdottir. 2011. Minerals and trace elements in Icelandic dairy products and meat. J. Food Comp. Analysis. 24(7):980986.

Schöne, F., M. Leiterer, P. Lebzien, D. Bemman, M. Spolders and G. Flachowsky. 2009. Iodine concentration of milk in a doseresponse study with dairy cows and implications for consumer iodine intake. J. Trace Elem. in Medic. and Biol. 23(2):84-
92.

Shahein, M.R. and E.S. Soliman. 2014. Fatty Acids and Amino Acids Composition of Milk and Resultant Domiati Cheese Produced from Lactating Cows Fed Different Energy and Protein Sources Rations. World J. Dairy Food Sci. 9(2): 184190.

Sokal R.R. and F.H. Rohlf. 1995. Biometry: the principles and practice of statistics in biological research. W.H. Freeman, New York.

Stawarz, R., G. Formicki and P. Massanyi. 2007. Daily fluctuations and distribution of xenobiotics, nutritional and biogenic elements in human milk in Southern Poland. J. Environ. Sci. and Health A Toxic Hazard Subst.Environ. Eng. 42(8):1169-1175.

Stojanovska, S., J. Tomovska, A. Krstanovski, J. Tasevska and M. Menkovska. 2018. Amino acid asparagine intake through milk enriched with supplements. J. Microbiol., Biotechnol. Food Sci. 7(4): 392-394.

Sun, Q., J.P. Lv, L. Liu, S.W. Zhang, X. Liang and J. Lu. 2014. Comparison of milk samples collected from some buffalo breeds and crossbreeds in China. Dairy Sci. Technol. 94(4):387-395.

Tripathi, R.M., Raghunath, R., Sastry, V.N. and T.M. Krishnamoorthy. 1999. Daily intake of heavy metals by infants through milk and milk products. The Sci. Total Environ. 227: 229-235.

WHO. 2007. Protein and amino acid requirements in human nutrition. WHO Technical Report Series 935. Geneva, Switzerland: WHO Press. Retrieved from http://apps.who.int/ iris/bitstream/10665/43411/1/WHO_TRS_93 5_eng.pdf?ua $=1$

Wu, G.Y. 2009. Amino acids: metabolism, function and nutrition. Amino Acids. 37 (1):1-17.

Wu, G.Y. and D. A. 1994. Free and proteinbound amino acids in sow's colostrum and milk. J. Nutr. 124(3):415-424.

Zamberlin S., N. Antunac, J. Havranek and D. Samaržija. 2012. Mineral elements in milk and dairy products. Mljekarstvo 62(2):111125.

Zurera-Cosano, G., Moreno-Rojas, R. and AmaroLopez, M. 1994. Effect of processing on contents and relationships of mineral elements of milk. Food Chem. 51(1):75-78. 